Why Gender Matters in Economics 



\section{Why Gender Matters in Economics}

MUKESH ESWARAN

PRINCETON UNIVERSITY PRESS

Princeton and Oxford 


\section{Copyright (C) 2014 by Princeton University Press}

Published by Princeton University Press, 41 William Street, Princeton, New Jersey 08540

In the United Kingdom: Princeton University Press, 6 Oxford Street, Woodstock, Oxfordshire OX20 1TW

press.princeton.edu

All Rights Reserved

Library of Congress Cataloging-in-Publication Data

Eswaran, Mukesh.

Why gender matters in economics / Mukesh Eswaran.

pages $\mathrm{cm}$

Includes index.

Summary: "Gender matters in economics—for even with today's technology, fertility choices, market opportunities, and improved social norms, economic outcomes for women remain markedly worse than for men. Drawing on insights from feminism, postmodernism, psychology, evolutionary biology, Marxism, and politics, this textbook provides a rigorous economic look at issues confronting women throughout the world-including nonmarket scenarios, such as marriage, family, fertility choice, and bargaining within households, as well as market areas, like those pertaining to labor and credit markets and globalization. Mukesh Eswaran examines how women's behavioral responses in economic situations and their bargaining power within the household differ from those of men. Eswaran then delves into the far-reaching consequences of these differences, in market and nonmarket domains. The author considers how women may be discriminated against in labor and credit markets, how their family and market circumstances interact, and how globalization has influenced their lives. Eswaran also investigates how women have been empowered through access to education, credit, healthcare, and birth control; changes in ownership laws; the acquisition of suffrage; and political representation. Throughout, Eswaran applies sound economic analysis and new modeling approaches, and each chapter concludes with exercises and discussion questions. This textbook gives readers the necessary tools for thinking about gender from an economic perspective. Addresses economic issues for women throughout the world, in both developed and developing countries Looks at both market and nonmarket domains Requires only a background in basic economic principles Includes the most recent research on the economics of gender in a range of areas Concludes each chapter with exercises and discussion questions"-Provided by publisher.

ISBN 978-0-691-12173-4 (hardback)

1. Women-Economic conditions. 2. Women-Employment. 3. Women-Social conditions. 4. Women in development. I. Title.

HQ1381.E89 2014

$305.4-\mathrm{dc} 23$

British Library Cataloging-in-Publication Data is available

This book has been composed in Sabon, with Scala and Scala Sans display, by Princeton Editorial Associates Inc., Scottsdale, Arizona

Printed on acid-free paper. $\infty$

Printed in the United States of America

109876654321 
For Viju, Nisha, and Megha 
